\title{
EXPORT DETERMINANT ANALYSIS: INDONESIA'S EXPORT TO SINGAPORE AND JAPAN CASE STUDY
}

DOI: 10.17261/Pressacademia.2019.1042

JBEF- V.8-ISS.2-2019(4)-p.114-126

\section{Euis Eti Sumiyati}

Jenderal Achmad Yani University, Economic and Business Faculty, Cimahi, Indonesia euis.eti@lecture.unjani.ac.id ORCID: 0000-0002-7567-3045

Date Received: April 29, 2019

Date Accepted: June 5, 2019

To cite this document

Sumiyati, E. Eti (2018). Export determinant analysis: Indonesia's export to Singapore and Japan case study. Journal of Business, Economics and

Finance (JBEF), V.8(2), p.114-126, DOI: 10.17261/Pressacademia.2019.1042

Permemant link to this document: http://doi.org/10.17261/Pressacademia.20189.1042

Copyright: Published by PressAcademia and limited licenced re-use rights only.

\begin{abstract}
Purpose- This study analyses the influence in Rupiah's exchange rate and the economic growth of trading partner country of Indonesia's export which are Singapore and Japan as the two biggest trading countries in Indonesia's export products in Asia region.

Methodology- Economy models used as analysis tools in this research are co-integration method and dynamic linear Error Correction Mechanism Model.

Findings- This study discovered that in long term, exchange rate has a negative impact to Indonesia's export, both for Singapore and Japan, while in short term the exchange rate does not have any correlation with export. Subsequently, economic growth of the trading partner country in long term has positive impact to export, while in short term it has no impact.

Conclusion- Findings of this empirical studies showed that in the long term, the effect of the exchange rate to Indonesia's export to Japan is greater compared to Singapore. Subsequently, the effect of Singapore's economic growth to Indonesia's export is greater compared to the effect of Japan's economic growth. The exchange rate has negative impact to Indonesia's export, both from Singapore and Japan. The result of this study has a probability to happen in Indonesia because Indonesia's export is still dominated by commodities with prices that tend to decrease, thus the effect of weakening rupiah is very small compared to export increase.
\end{abstract}

Keywords: Exchange rates, export, economic growth

JEL Codes: M20, M21, N10

\section{INTRODUCTION}

Indonesia's economy is an open economy that marked with the presence of economic relationship and relationship in other fields with many countries in the world. Currently, there are nearly no country that does not maintain a relationship with other countries in relation to the various needs of their people and the ever-increasing population in every country. This condition prompts inter-country transactions such as export and import activities. Indonesia's export opportunity to other countries has been present since the past, even from the formation of General Agreement on Tariffs and Trade (GATT) and World Trade Organization (WTO) which means the opportunity should become wider noting that various type of obstacles in WTO member countries has been minimised. Moreover, Indonesia has better export opportunity due to the abundancy in natural resource and plenty of labours. However, Indonesia has not wholly experience the positive impact from the free-trade system proposed by WTO.

Global monetary crisis in $\mathbf{2 0 0 8}$ had given negative impact to world trade, including the impact to Indonesia's export where the growth of Indonesia's export on 2009 reached minus 17.27\% which declined drastically from 2008 that reached 16.22\%. Export's performance increased on 2010 with growth of 33.24\%, where it was the highest record throughout Indonesia's export history. However, the export growth declined again on 2011. Moreover, in 2012, it reached minus $8.85 \%$ and in 2015 it reached $10.47 \%$. 
Although in 2016 and 2017 Indonesia's export experienced an increase, until November 2018 export returned to decline as shown in Figure 1 below.

Figure 1: Growth of Indonesia's Export Value in Period of $2006-2018$ (\%)

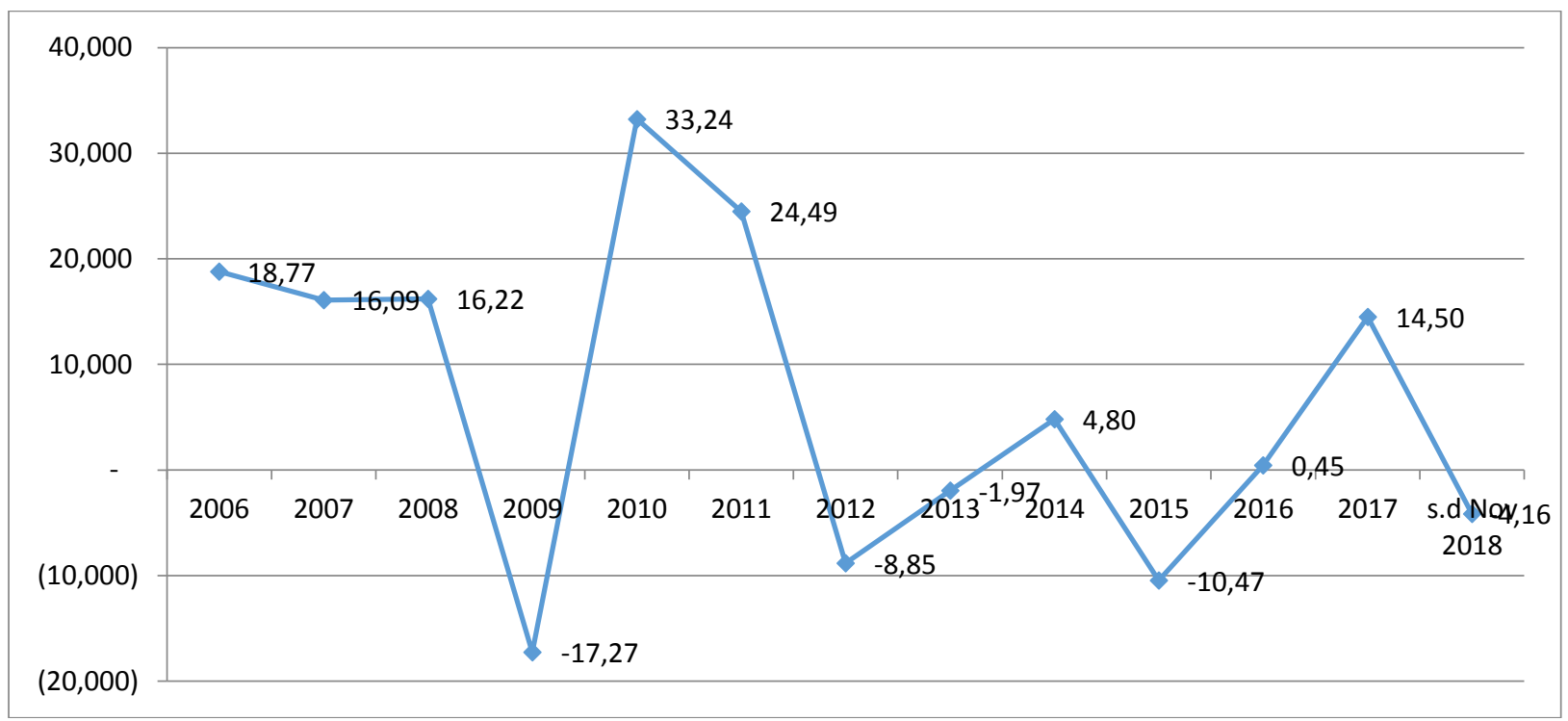

Source: Indonesia's Statistic of Economy and Financial, Bank of Indonesia (various periods), processed data

Majority of Indonesia's exports are aimed at main trading partner countries, such as the United States, Europe, East Asia (particularly Singapore, Japan and China). On 2006-2017, Asia and Middle East countries were ranked first as countries that traded with Indonesia's export product which reached $69.6 \%$ in average while the second and third ranks were European countries and the United States which were $12.3 \%$ and $12 \%$ respectively as shown in Figure 2 below.

Figure 2: Average Distribution Percentage of Indonesia's Export Based on Country of Destination, Period of 2005 - 2017

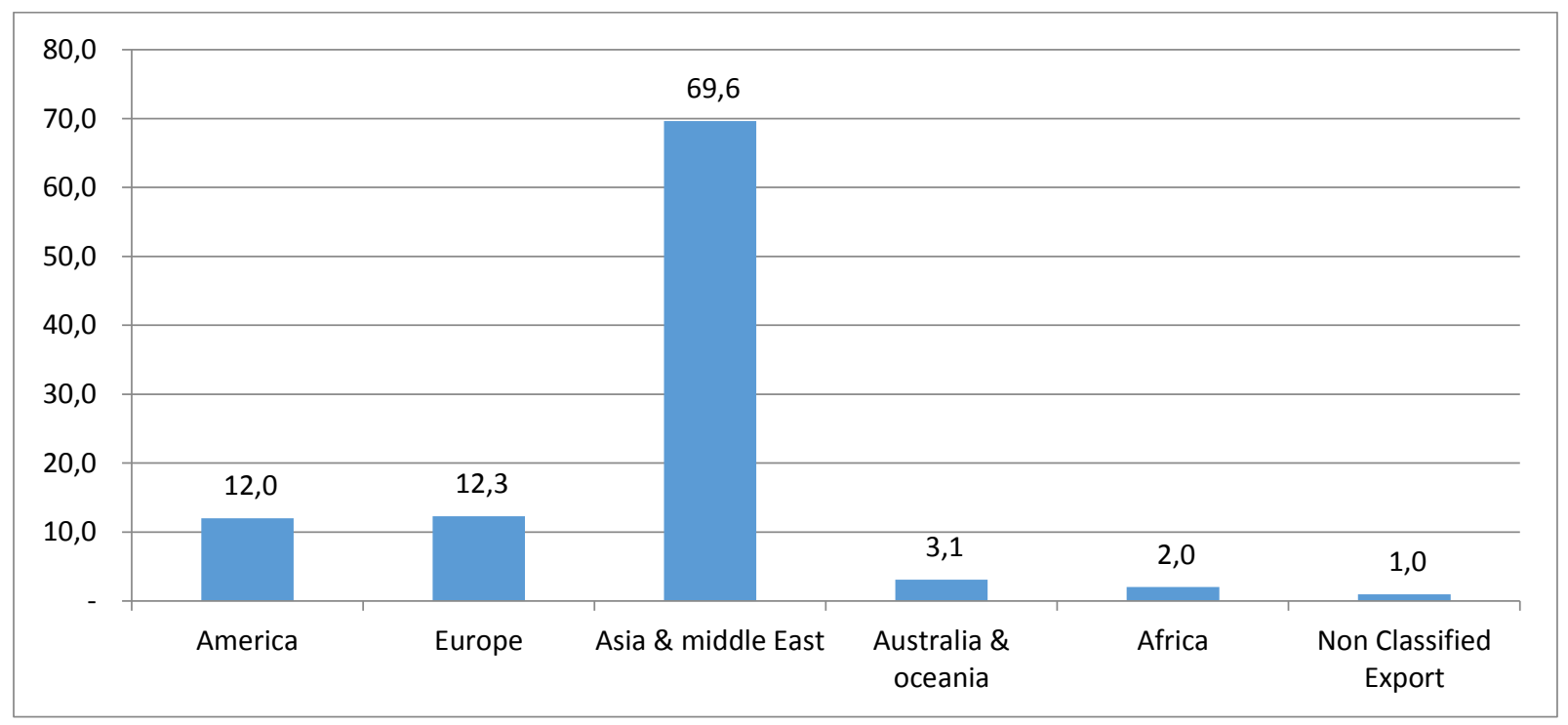

Source: Indonesia's Statistic of Economy and Financial, Bank of Indonesia (various periods), processed data 
In Asia and Middle East region itself, the average of Indonesia's export on 2006-2017 generally went to ASEAN region of 29.2\%, followed by Japan of $23.9 \%$ and People's Republic of China of $14.4 \%$ as shown in Figure 3 below. Thus, it can be concluded that Asia region is a highly potential market for Indonesia's export, particularly ASEAN region where Indonesia and other Southeast Asia countries are integrated in ASEAN Economic Community which aimed to be an effort to widen regional integration to achieve economic scale (International Directorate - Bank of Indonesia, 2015).

Figure 3: Average Distribution Percentage of Indonesia's Export to Asia and Middle East Countries in Period of 2005-2017

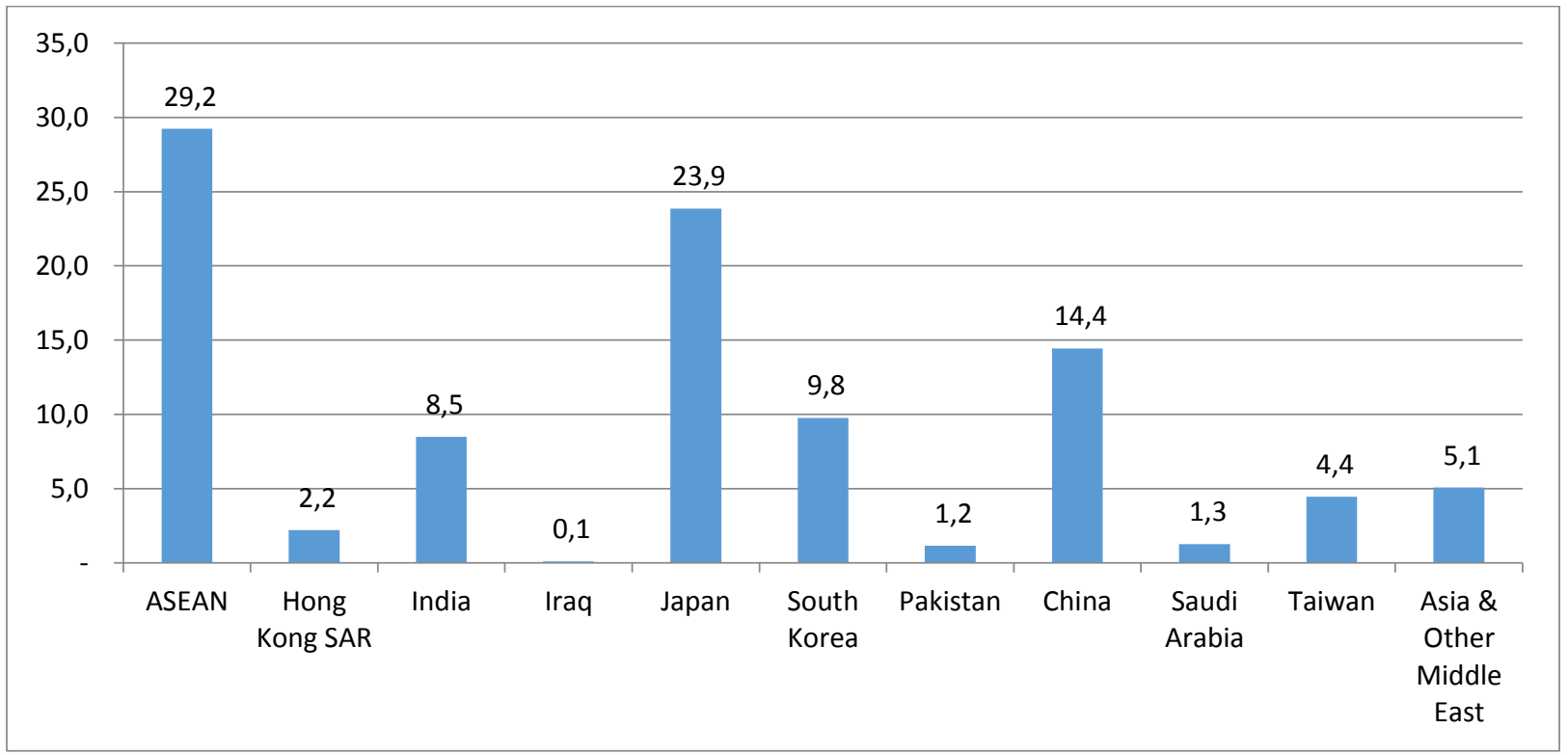

Source: Indonesia's Statistic of Economy and Financial, Bank of Indonesia (various periods), processed data

In ASEAN region, the majority of Indonesia's export on 2005-2017 went to Singapore for $40.8 \%$, followed by Malaysia for $24.9 \%$, and Thailand for 15\%. Moreover, the average growth of Indonesia's export to ASEAN region on $2006-2017$ reached $8.7 \%$ as shown in Figure 4 below.

Figure 4: Average Distribution Percentage of Indonesia's Export to ASEAN in Period of 2005-2017

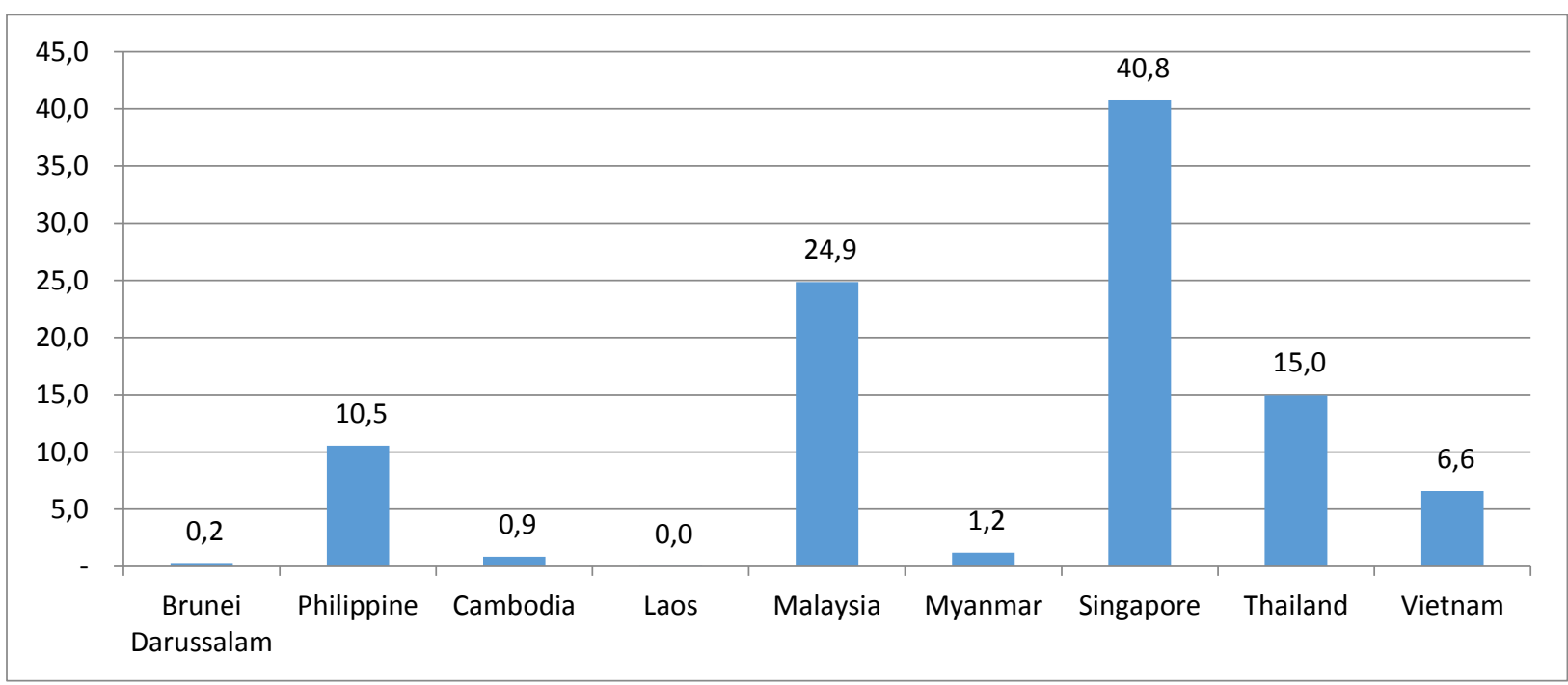

Source: Indonesia's Statistic of Economy and Financial, Bank of Indonesia (various periods), processed data 
Indonesia's export fluctuation is closely related to various influence factors, such as fluctuation in exchange rate as one of the international factors. If the exchange rate is stated on direct term (Rupiah over USD), therefore when the exchange rate is high (rupiah strengthens), domestic products will become relatively more expensive compared to international products. This condition encourages domestic population to buy more import products whereas international population buys more domestic products in lesser amount and vice versa. Figure 5 below illustrates export growth and exchange rate change (Rp/USD \$). It is interesting to note that on the period of 2009-2010 where rupiah experienced strengthening yet export increased drastically. Similarly, on period of 2010-2012, Rupiah weakened yet export was also decreased.

Figure 5: Growth of Indonesia's Export and Change of Nominal Exchange Rate on Period of 2006-2018

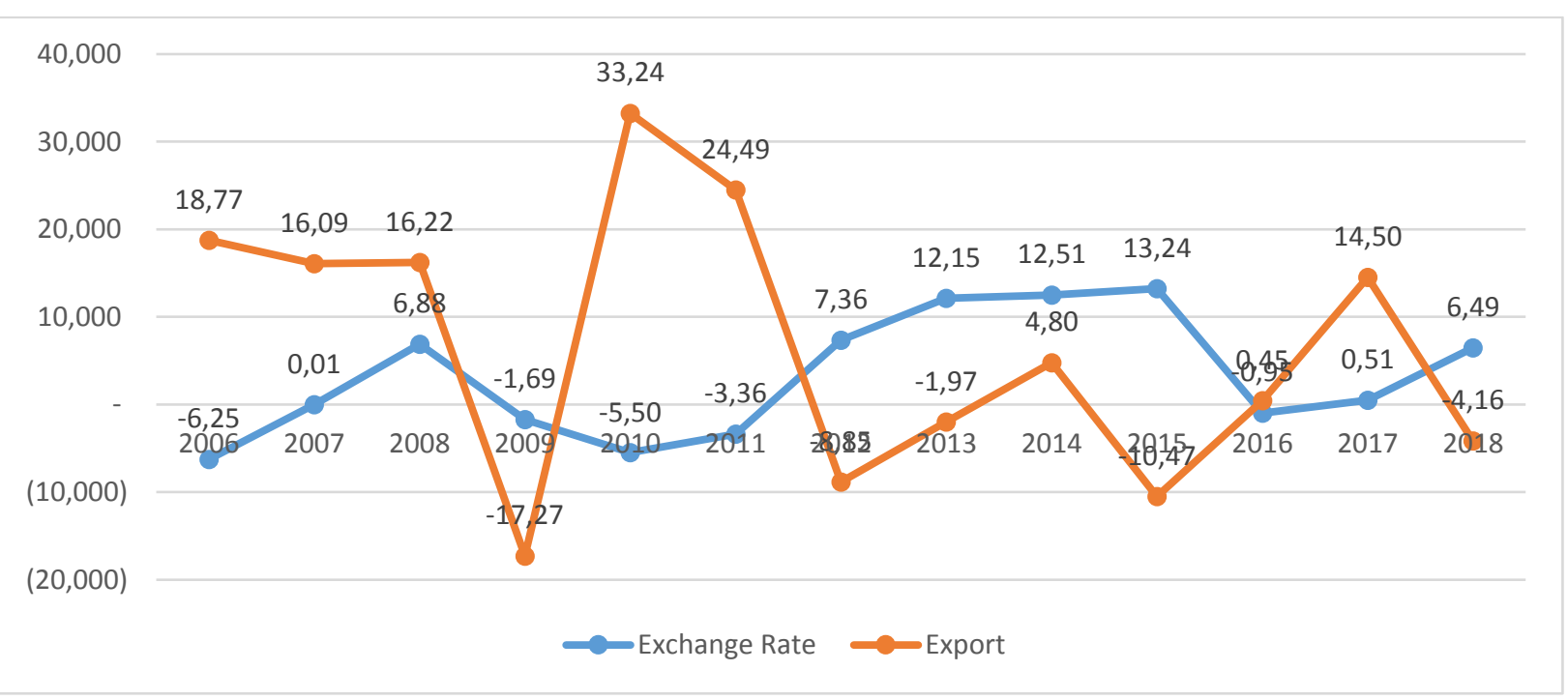

Source: Indonesia's Statistic of Economy and Financial, Bank of Indonesia (various periods), processed data

Other than exchange rate, the economic growth of export destination country (trading partner country) is another factor that influences export. The economic growth directly corresponds to the country's economic performance and the country's increasing ability to buy international products. Based on the exporting country, the economic condition of the trading partner country can be a consideration in performing export activity. Figure 6 below shows the average economy growth (PDB Growth) of a number of countries/regions on the period of 2010-2017. Countries/regions that have highest rank of average PDB growth are Asia region (PRC, South Korea, Hongkong, Taiwan and India) which reached $5.17 \%$. It was then followed by ASEAN-5 region of $5.15 \%$.

Figure 6: Average PDB Growth of Various Countries/Regions on Period of 2010-2017

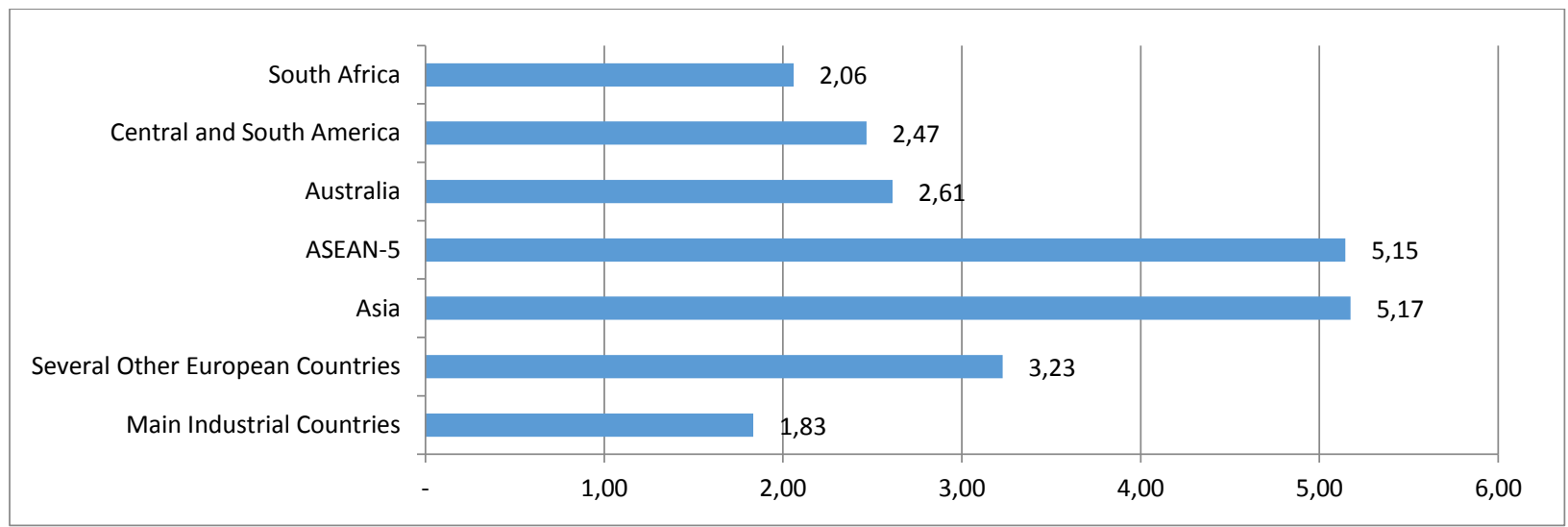

Source: Indonesia's Statistic of Economy and Financial, Bank of Indonesia (various periods), processed data 
Interestingly, on the period of 2011-2012, where the average economic growth of ASEAN countries excluding Indonesia experienced growth from $3.5 \%$ to $5.3 \%$, Indonesia's export value experienced decrease from $19 \%$ to $16.8 \%$. The relationship between exchange rate and export is expected to show a positive direction. The relationship between the two variables has gained interest of various economy researchers. Past studies that determined exchange rate as one of the factors that influence export are Hock-Tsen Wong and Hock Ann (2016), who reported the volatility of exchange rate has significant impact to real export and negative or positive impact on some types of export products. Chit, Myint M. (2008) studied the impact of exchange rate volatility to bilateral export in ASEAN-China Free Trade Area (ACFTA). Empirical result showed that the volatility of bilateral real exchange rate has statistically significant negative impact to bilateral export to ACFTA countries. Moreover, research by Solakoglu and Demirağ (2008) found that there is no negative nor positive relationship between volatility and real export. Cheung and Sengupta (2013) discovered significant and strong negative impact from the currency appreciation and currency volatility to company's export target in India. Companies that export services are more influenced by the fluctuating exchange rate compared to companies that export products. Grier and Smallwood (2013), found that the uncertainty of Real Exchange Rate (RER) has a negative impact to trading for less developing countries. Ginting, Ari Mulianta (2013) reported that exchange rate in both long and short term has a negative and significant impact to Indonesia's export.

Figure 7: Average PDB Growth of ASEAN-4 Region and Growth of Indonesia's Export to ASEAN-4 Region on Period of 2010-2017

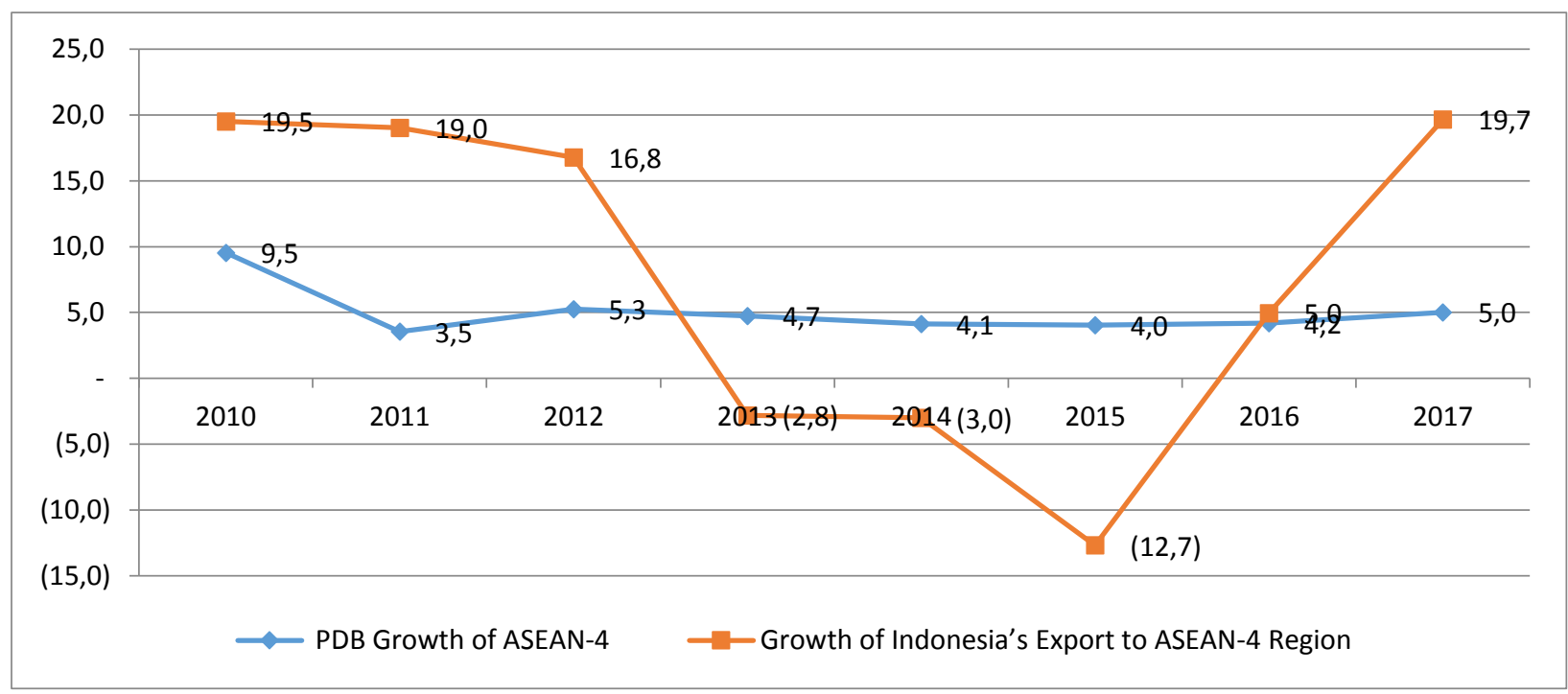

Source: Indonesia's Statistic of Economy and Financial, Bank of Indonesia (various periods), processed data

Based on the explanation above, it is interesting to appreciate the factors that influence Indonesia's export to Asia region, particularly Singapore as the biggest export destination country in ASEAN countries and Japan as the second biggest export destination country after ASEAN in period of 2012 quartile I to 2018 quartile II. The time period was determined based on the consideration that Indonesia's export demand has recently increased again from 2012 after it experienced a significant decrease since 2010 due to the effect of global economy crisis. Whereas the title of this research is "Export Determinant Analysis: Indonesia's Export to Singapore and Japan Study Case".

Whereas the aim of this research is to understand how the exchange rate and economic growth of trading partner countries (Singapore and Japan) influence Indonesia's export, both partially and simultaneously.

\section{LITERATURE REVIEW}

\subsection{Nominal Exchange Rate, Real Exchange Rate, and its Relationship with Balance of Trade}

Exchange rate of a country's currency is divided to nominal exchange rate and real exchange rate. Nominal exchange rate is a relative price of both countries' currency (Mankiw, 2009). For example, USD 1 is valued at RP 13.000 in money market. Meanwhile, real exchange rate is related to the relative price of products in both countries. Real exchange rate indicates the grade, where economic agents can trade products from a country with products from another country. Real exchange rate 
between two currencies of both countries is calculated from nominal exchange rate multiplied by the index price ratio of both countries. The relationship between real exchange rate and nominal exchange rate can be formulated as below:

$\mathrm{REER}=\mathrm{ER} *(\mathrm{FP} / \mathrm{DP})$

Where:

REER : Real Effective Exchange Rate

ER : Nominal Exchange rate stated in direct term (in Rupiah/1 Dollar) or indirect term (Dollar/1 Rupiah)

FP : Foreign Price Index of the trading partner price (foreign countries)

DP : Domestic Price/Index of domestic price

Based on the equation above, it can be explained that generally the competitiveness of foreign trading is determined by two factors, which are ER and the ratio of price between two countries. If ER (direct term) increases (appreciated), with the assumption of constant price ratio, then a positive relationship is made on the balance of trade. This is because higher ER indicates the price of Indonesia's product (domestic) is relatively low compared to other products' price, because the same number of dollar will give more rupiah. Conversely, by assuming non-fluctuating currency, competitiveness is highly determined by the country's ability (domestic) or monetary authority in controlling the flow of price through various instruments under their obligation. In short, real exchange rate of a country will affect the microeconomic condition of a country, particularly with net export and balance of trade. This impact can be summarised in a relationship between real exchange rate and net export or balance of trade (Mankiw, 2009).

$N X=f\left(e, Y, Y^{*}\right)$

The equation above means that the net export (balance of trade) is a function of real exchange rate. Where NX is net export, e is nominal exchange rate, $Y$ is domestic GDP and $Y^{*}$ is combined GDP of trading partner countries. The relationship between real exchange rate and net export from Mundell - Flemming's idea is negative (currency rate measurement is approximated with indirect term). However, if the exchange rate is stated in direct term (Rupiah per USD), Flemming's idea can be drawn in an IS (Investment Saving) curve with positive slope coefficient. In other words, higher REER indicates an event where Rupiah exchange rate is decreased or depreciated. Low REER in context of direct term can be translated as domestic products being relatively expensive compared to foreign products, which means low competitiveness. Due to low competitiveness, export decreases and inversely import increases. This means the low REER (strengthens of domestic currency relative to trading partners) suppress the balance of trade, thus domestic people will only buy a small number of import products. Inversely when the currency rate is high, domestic products will become more expensive compared to overseas products. This condition encourages domestic people to buy more import products and overseas people to buy domestic products in smaller number.

\subsection{Small Open Economy with Floating Exchange Rate System}

There are two main factors on international trading theory (Salvatore, 2013), one is the basis for trade and the gains from trade. Second is the pattern of trade. The first reason countries are trading is because there is a difference between one country and another, such as difference in natural resources, climate and ability to produce goods. A country can only do trading if that country receives benefit from the trade. One of the benefits of international trade is getting access to goods that they cannot produce by themselves. The second reason why countries trade with each other is to achieve economies of scale in production. This means, if every country can limit their production activity to produce particular products in some number, then that country has an opportunity to centralise attention and every type of their resources to produce those particular products in bigger scale and subsequently become more efficient compared to the case where that country tried to produce various type of products simultaneously (Krugman and Obstefeld, 2004). The use of floating exchange rate system by a country's economy will produce fluctuating exchange rate that independently adjust with the change in economy condition. Thus, in a case where Central Bank increases their money offering, assuming that the price index is constant, this system will cause real balance increase.

In small open economy, the interest rate is determined by global interest rate. Increase of money offer will suppress domestic interest rate, thus capital outflow of investor will happen to gain higher reception. The presence of higher capital outflow impact the supply of domestic currency which further depreciate the exchange rate. The depreciation of exchange rate will decrease the price of domestic goods compared to overseas goods thus increases export. This means that in small open economy, monetary policy from exchange rate highly influences output and income. In floating exchange rate system, depreciation and appreciation of exchange rate will affect both import and export. If exchange rate experiences depreciation, then the domestic currency decreases relative to overseas currency, and subsequently export volume will increase. 
The impact of fluctuating exchange rate to export gains interest of some economic researchers. Solakoglu and Demirağ (2008) estimated the effect of exchange rate volatility with 143 companies in Turkey on 2001-2003 as samples. The result showed that there is no negative nor positive impact between volatility of exchange rate and real export.

Cheung and Sengupta (2013) explored the effects of real effective exchange rate (REER) to companies in export segment of nonfinancial sector in India in 2010-2010. The result showed that there is a negative and significant impact from currency appreciation and exchange rate volatility to companies in export segment of non-financial sector in India. Moreover, it was discovered that those companies in non-financial sector responded asymmetrically to exchange rate. The effect of change in REER is negatively encouraged by the appreciation effect compared to depreciation effect, India's companies that has smaller export segment tends to give greater respond to change and volatility of REER. Service export companies are tend to be more influenced by the fluctuation of exchange rate compared to goods export companies.

Grier and Smallwood (2013) researched the uncertainty effect to trading by using approximation model of GARCH multivariate. By using the data from both developed and developing countries, the result shows that Real Exchange Rate (RER) has negative impact to trading on less developing countries. Moreover, it was deducted that the uncertainty in RER tends to be related with the real exchange rate appreciation. Positive shock produces negative response while positive response that is relatively smaller, particularly in developing countries.

Marilyne Hucher-Bourdon and Jane Korinek (2012) performed a research regarding volatility dynamics in Brazil, Chile, New Zealand and Uruguay for the period of 1990-2013. Estimation methods used were GARCH and IGARCH model. The research result showed that the raw material export depends on the demand and international price, yet the increase in real exchange rate volatility or real exchange rate (RER) gives variable impact to those four countries. The potential impact from the exchange rate volatility, global demand and international price to export used Johansen methodology and impulse respond. The result showed that export is positively influenced by global demand and international price, however RER volatility does not give significant impact except in Uruguay where RER volatility influenced export negatively both in short and long term.

Chit, Myint M. (2008) studied the impact of exchange rate volatility to bilateral export in ASEAN-China Free Trade Area (ACFTA) using general gravity model. Research was done using panel data with samples of 20 throughout period of 1982: Q1 to 2005: Q1 using fixed effect model and random effect model methods. Unit root test and panel co-integration were used to confirm the long term relationship between variables. Empirical result showed that the volatility of bilateral real exchange rate has a statistically significant negative impact to bilateral export of ACFTA countries.

Bustaman, A. \& Jayanthakumaran, K. (2007) researched the long and short term impact of exchange rate volatility to main commodity export of Indonesia to the United States in monthly period of 1997-2005. The estimation of co-integration relationship was obtained by using ARDL test procedure. The estimation of short-run dynamics was obtained using errorcorrection model. The result indicated that there are significant negative and positive coefficients between various commodities. However, in long term, majority of commodity tends to support traditional view where higher exchange rate impacts to higher volatility and decreases international trading. The uncertainty of exchange rate in production and export depends on the risk index relative to various commodities.

Hock-Tsen Wong and Hock-Ann (2016) studied the effect of exchange rate volatility to bilateral export of manufacture goods from Malaysia to China. The result showed that exchange rate volatility has a significant impact to real export. Moreover, exchange rate volatility has both negative and positive impact to real export. Export will be more variable by focusing on intraregion trading which is the ASEAN Economic Community.

Shinta Fitrianti (2017) researched the long and short term impact of exchange rate volatility to real export of Indonesia to its main trading partners, which are Japan and the US. This study used monthly data from January 1998 to October 2015 with structural break of global economy crisis in 2008. Furthermore, commodity prices were also included as an independent variable. Long term co-integration was estimated using Autoregressive Distributed Lag (ARDL) limit test, while short-term dynamics was determined using Error Correction Model (ECM). The findings indicated that the Rupiah volatility to Japanese yen decreases Indonesia's export to Japan, both in short and long term. Fluctuation of Rupiah to US dollar increases Indonesia's export to the US in short term, however this impact does not occur in long term. On the other hand, there is no shock impact to commodity prices, except long term export to Japan. 


\section{DATA AND METHODOLOGY}

This research used quarterly period of time series data from Q1. 2012 to Q2. 2018. Economy models used as an analysis tool in this research were co-integration method and dynamic linear Error Correction Mechanism (ECM) model. The basis of applying these analysis tool was the fact that data of time series of macroeconomic variables generally has a non-stationary trend. In relation to the forming of such dynamic linear model, there are some testing that need to be performed, such as stationarity test, co-integration test and error correction test (Ekananda, 2016).

\subsection{Data Stationary Test}

Stationary is one of the preconditions in econometric model for time series data. Stationary data is data that shows constant mean, variance and auto-covariance (in lag variation) every time data is used, which means with stationary data, time series model can be considered more stable (Gujarati, 2002: 798). If one of the data used in the model is not stationary, thus the validity and stability of the data should be re-considered because the regression result that originated from non-stationary data will cause spurious regression. Stationary test that will be done in this research is unit roots test (Augment Dickey-Fuller).

Unit roots test was developed by Dickey and Fuller and known as DF test or Augmented Dickey Fuller (ADF test), which is a method to test the degree of integration to test the stationary of the analysed data (Gujarati, 2003: 814-817). The unit roots test procedure is estimated in three auto-regressive equations (Gujarati, 2003: 815) as below:

$Y t=\rho \mathrm{t}-1+\mu \mathrm{t}$ (without intercept)

$\mathrm{Yt}=\beta_{1}+\rho \mathrm{Yt}-1+\mu \mathrm{t}$ (with intercept)

$Y t=\beta_{1}+\beta_{2} T+\rho Y t-1+\mu t$ (with intercept and trend)

As explained above, data stationary test is needed to gain data validity. If one of the data used in the model is not stationary, then the validity and stability of that data need to be reconsidered because the regression result from non-stationary data will cause spurious regression. Thus, the procedure of empirical analysis in this research is started by stationary test on various economic variable data using data stationary test which used for every variable in research model based on Augmented Dickey Fuller Test (ADF test), in which the calculation was assisted using Eviews program. The result of stationary test calculation on first difference degree with equation of $\mathrm{dYt}=\mathrm{Yt}-\mathrm{Yt}-1$ shows every variable is stationary, as shown in Table 3.1 below.

Table 3.1: Result of Data Stationary Test: Dickey-Fuller Test

\begin{tabular}{|c|c|c|c|c|}
\hline \multirow[t]{2}{*}{ Country } & \multirow[t]{2}{*}{ Variable } & \multicolumn{2}{|c|}{ P-Value ADF Test Statistic } & \multirow[t]{2}{*}{ Stationary } \\
\hline & & Level & First Difference & \\
\hline \multirow{3}{*}{ Singapore } & LNX_to SPR & 0.6111 & 0 & $1^{\text {st }}$ difference \\
\hline & EG_SPR & 0.3486 & 0.0166 & $1^{\text {st }}$ difference \\
\hline & LN ER & 0.3207 & 0.0237 & $1^{\text {st }}$ difference \\
\hline \multirow{3}{*}{ Japan } & LNX_to JPN & 0.2564 & 0.0003 & $1^{\text {st }}$ difference \\
\hline & EG_JPN & 0.0003 & 0.0004 & Level\& $1^{\text {st }}$ difference \\
\hline & LN ER & 0.3207 & 0.0237 & $1^{\text {st }}$ difference \\
\hline
\end{tabular}

LN ER: Natural logarithm of nominal exchange rate (in direct term Rp/USD); EG_SPR: Singapore's economic growth; EG_JPN: Japan's economic growth

\subsection{Co-integration Test}

Co-integration test is a continuation of unit roots test and integration degree test. If two or more variables have different integration degree, such as $X=I(1)$ and $Y=I(2)$, then those two variables are not co-integrated. Co-integration test aims to determine whether there is a balance between observed variables. Co-integration concept is related to the presence of longterm balance where the economy system is convergent all the time as intended by the theory and a method to perform testing to theory. The method used to estimate long term relationship is Engle-Granger method (Gujarati, 2003:823) which is by testing the stationarity of the error term. The basis of co-integration test application is the fact that majority of macroeconomic data produce spurious regression relationship. Thus, co-integration method is a solution to such issue. 
Co-integration test is one of the tests in dynamic model where the aim of this test is to determine whether a long term relationship exists between variables. Co-integration test uses Engle-Granger method, while Johansen Co-integration approximation was used to obtain long term equation on the research model proposed. The ADF test result from residual (ECT) for the research model can be seen from Table 3.2 and 3.3 below.

Table 3.2: The Result of ADF Test Error Correction Term (ECT) of Singapore

Null Hypothesis: RES1 has a unit root

Exogenous: Constant

Lag Length: 0 (Automatic - based on SIC, maxlag=5)

\begin{tabular}{|c|c|c|c|}
\hline & & t-Statistic & Prob.* \\
\hline \multicolumn{2}{|c|}{ Augmented Dickey-Fuller test statistic } & -4.013266 & 0.0051 \\
\hline \multirow[t]{3}{*}{ Test critical values: } & $1 \%$ level & -3.724070 & \\
\hline & $5 \%$ level & -2.986225 & \\
\hline & $10 \%$ level & -2.632604 & \\
\hline
\end{tabular}

*MacKinnon (1996) one-sided p-values.

Table 3.3: The Result of ADF Test Error Correction Term (ECT) of Japan

Null Hypothesis: RES2 has a unit root

Exogenous: Constant

Lag Length: 5 (Automatic - based on SIC, max lag=5)

\begin{tabular}{llll}
\hline & t-Statistic & Prob. $^{*}$ \\
\hline Augmented Dickey-Fuller test statistic & -3.269741 & 0.0306 \\
\hline Test critical values: & 1\% level & -3.808546 & \\
\hline & 5\% level & -3.020686 & \\
\hline & 10\% level & -2.650413 & \\
\hline
\end{tabular}

*MacKinnon (1996) one-sided p-values.

Based on table 3.2 and 3.3 above, it can be seen that ADF value for Error Correction Term (ECT) is a significant value which indicated by $\mathrm{P}$-value that is smaller than significant level of $5 \%$. Based on this condition, it can be concluded that observed variables in this research co-integrates in the same degree. This means that there is a long term balance between every variables. In other words, exchange rate and economic growth variables have a correlation and co-integrate with export variable.

\subsection{Error Correction Mechanism (ECM) Dynamic Model}

If the result of Engle-Granger test shows that researched variables are co-integrated, a model is needed for dynamic adapting process of variables in the model, which called Error Correction Mechanism (ECM). This model is used to determine how the disequilibrium in short term will be corrected or adjusted to reach long term balance which illustrated by error correction term variable. Furthermore, the model specification of this research is as below:

1. $\quad$ LNX_To SPR $=\alpha_{0}-\alpha_{1} L N$ ER $+\alpha_{2}$ EG_SPR $+\varepsilon$

2. $\quad$ LNX_To JPN $=\beta_{0}-\beta_{1} L N E R+\beta_{2} E G \_J P N+\varepsilon$

Where:

LNX_To SPR = Natural logarithm of export value to Singapore

LNX_To JPN =Natural logarithm of export value to Japan

LN ER =Natural logarithm of nominal exchange rate (in direct term Rp/USD)

EG_SPR = Singapore's economic growth

EG_JPN = Japan's economic growth 


\section{FINDINGS AND DISCUSSIONS}

\subsection{Indonesia's Export Growth to Singapore and Japan}

Indonesia's export growth to Singapore and Japan tends to decrease as shown in Figure 8. The dramatic decrease of export to Singapore happened in the period of 2012-2013 and 2014-2015 as well as 207-2018. While the huge decrease of export to Japan occurred in period of 2011-2012 and 2013-2014 as well as 2017-2018. The decrease in export influenced the general export growth as those two countries are considered as the top two countries in Asia region that also buy many export products of Indonesia. The decrease in export was probably happened due to the effect of the ever-increasing global economy crisis. The weakening of economic condition of destination country can also impact those countries to decrease their demand to goods and services from Indonesia.

Figure 8: Export growth to Singapore and Japan in the Period of 2011-2018 (\%)

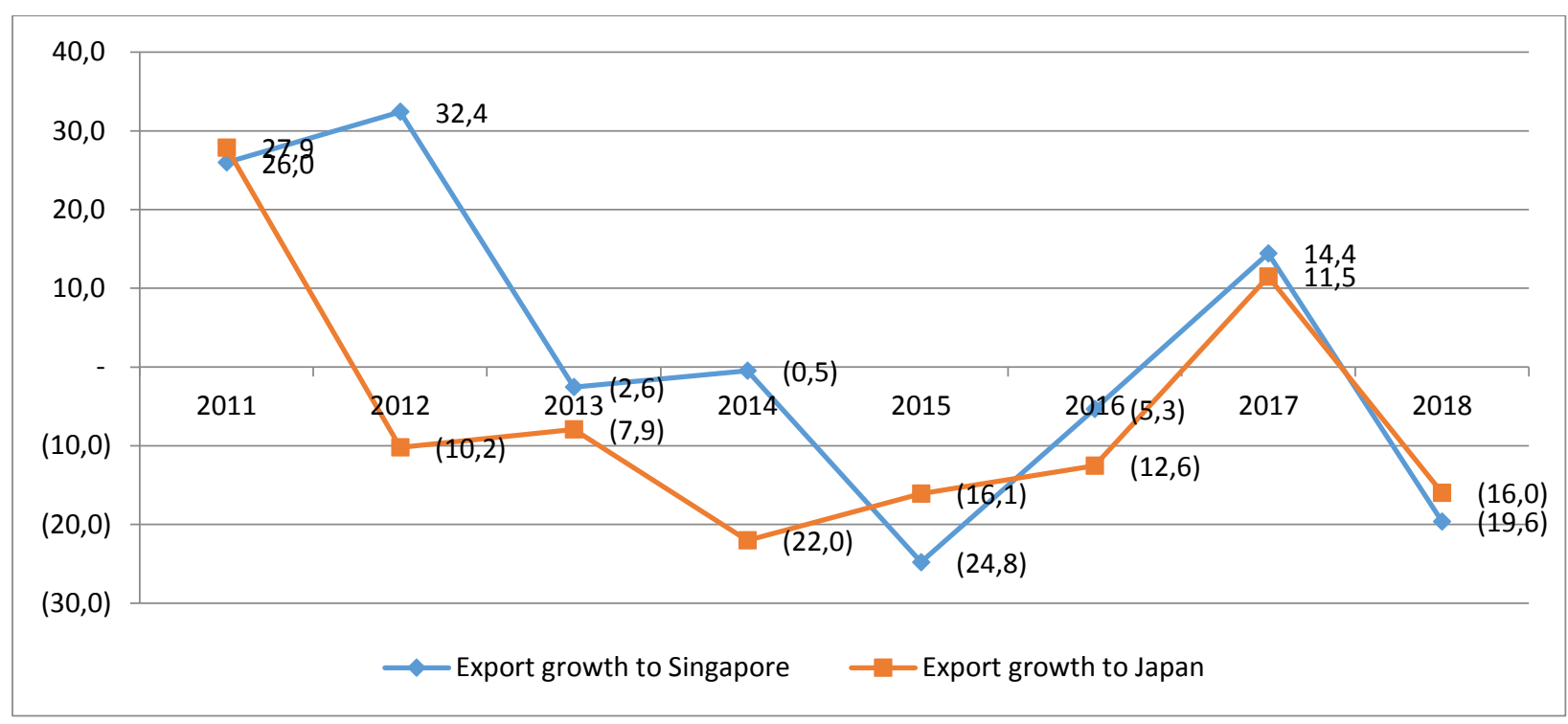

Source: Indonesia's Statistic of Economy and Financial, Bank of Indonesia (various periods), processed data

\subsection{Dynamic Model Analysis (Long Term Model Estimation)}

Co-integration concept stated that in the case where one or more variables are not-stationary and co-integrated, then the linear combination between variables in the system will work in stationary nature, thus a stable long term equation system can be achieved. Table 4.1 below shows the model of long term equation for the model of Indonesia's export to Singapore and Japan. The specification of long term equation model for Indonesia's export model is as follows:

1. LNX_To SPR $=21.96939-0.746412$ LN ER +0.033248 EG_SPR

2. LNX_To JPN $=29.52396-1.503500$ LN ER +0.029554 EG_JPN

Based on the equations above, it can be understood that in long term, the exchange rate in the form of direct term (Rp/USD) has negative impact to Indonesia's export, both for Singapore and Japan as the destination. This is shown by $\mathrm{P}$ value smaller than $1 \%$. Moreover, by observing the coefficient value of Singapore as trading partner of -0.746412 and Japan of -1.5035 , it can be perceived that by considering the constant economic growth, every $1 \%$ increase of exchange rate (which indicates Rupiah to be depreciated) impacts export decrease to Singapore of $0.75 \%$ and export decrease to Japan of $1.5 \%$. 
Table 4.1: Estimation Result of Long Term Export Model

\begin{tabular}{lllll}
\hline $\begin{array}{l}\text { Independen } \\
\text { Variable }\end{array}$ & Singapore & Japan & \\
\cline { 2 - 5 } & Coefficient & $\begin{array}{l}\text { Prob. } \\
\text { (1- tailed) }\end{array}$ & Coefficient & $\begin{array}{l}\text { Prob. } \\
\text { (1-tailed) }\end{array}$ \\
\hline LN ER & -0.746412 & $0.0000^{* *}$ & -1.503500 & $0.0000^{* *}$ \\
\hline EG & 0.033248 & $0.0071^{*}$ & 0.029554 & $0.0369^{*}$ \\
\hline $\mathrm{C}$ & 21.96939 & 0.0000 & 29.52396 & 0.0000 \\
\hline R-squared & 0.637605 & & 0.855459 & \\
\hline Adjusted R-squared & 0.606093 & & 0.842890 & \\
\hline Prob(F-statistic) & 0.000009 & & 0.000000 & \\
\hline
\end{tabular}

Noted: ** Significant at $\alpha 1 \%{ }^{*}$ Significant at $\alpha$ 5\%

This is not in agreement with the research hypothesis that theoretically, the weakening of Rupiah to US Dollar should be able to encourage export because products price is cheaper when converted to US Dollar thus become more competitive. The study result may happen for Indonesia's case because Indonesia's export is still dominated by commodity with price that still tend to be decreased thus the influence of the Rupiah's weakening is very small compared to increase in export as shown in Figure 9 below.

Figure 9: The Growth of Index Price of Commodities in World Market and Change in Exchange Rate (RP/USD) in Period of 2011-2016

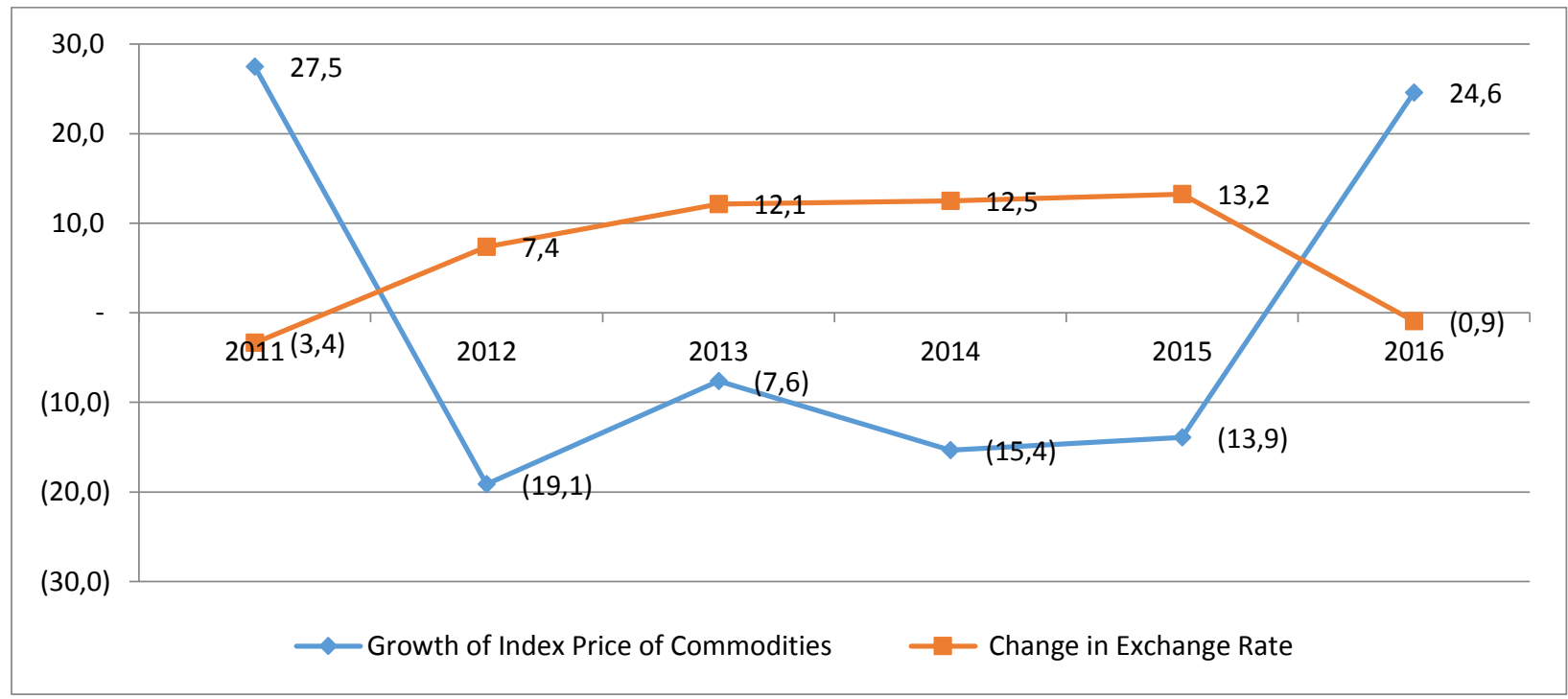

Source: Indonesia's Statistic of Economy and Financial, Bank of Indonesia (various periods), processed data

Moreover, the result of this research discovered that in long term, the economic growth of the trading partners of Indonesia (Singapore and Japan) has positive impact to Indonesia's export. This is indicated by P value smaller than $5 \%$. From Table 4.1 and equation above, it can be concluded that by assuming constant exchange rate, in every $1 \%$ of economic growth increase of Singapore and Japan, export to Singapore and Japan will increase by $0.03 \%$. This is in agreement with the research's hypothesis. The increasing overseas economic growth indicates the economic condition of that country is in good condition and can increase the demand of export goods from other countries.

After the regression of long term export equation above is determined, then the next step is to determine the residual from the equation. The result will show whether correction to export is due to disequilibrium of exchange rate and economic growth. Residual from export equation will be included as an ECT variable in short term equation. From the short term equation based on the estimation result using ECM, the estimation result is shown on Table 4.2 that demonstrates the coefficient value of Error Correction Term (ECT) on the model is significant and negative to estimate export in Indonesia. The estimation result of Error Correction Model (ECM) above shows that in short term, exchange rate and economic growth of trading partner countries have 
no effect on export. This is shown by $\mathrm{P}$ value greater than $5 \%$. However, the variation of two variables can simultaneously elaborate the variance of export variable of $39 \%$ and $61 \%$ of the rest can be elaborated by the variance of other variables outside the model. Based on the available data, the estimation model for Indonesia's short term export can be summarised in the equation below:

1. $\quad D\left(L N X \_T O S P R\right)=-0.002245-0.339532 D($ LNKURS $)+0.009830 D\left(P E \_S P R\right)-0.710213 * E C T$

2. $\quad D\left(L N X \_T O J P N\right)=-0.025031-0.028575 D($ LNKURS $)+0.003397 D\left(P E \_J P N\right)-0.544135 * E C T$

Based on the short term equation using ECM method, ECT coefficient can be calculated. This coefficient measures regressand's respond in every period that deviate from equilibrium. According to Widarjono (2007), coefficient of non-equilibrium ECT correction is in a form of absolute value which elaborates the time needed to determine equilibrium value. The ECT coefficient of -0.710213 means that the difference between export to Singapore and the equilibrium value of 0.710213 will be adjusted in the duration of 1 quartile. Thus, ECT coefficient of - 0.544135 means that the difference between export to Japan and the equilibrium value of 0.544135 will be adjusted in the duration of 1 quartile.

Table 4.2: Estimation Result of Indonesia's Export ECM

\begin{tabular}{lllll}
\hline \multirow{2}{*}{ Independent Variable } & \multicolumn{2}{c}{ Singapore } & \multicolumn{2}{c}{ Japan } \\
\cline { 2 - 5 } & Coefficient & Prob. & Coefficient & Prob. \\
\hline $\mathrm{D}(\mathrm{LN}$ ER) & -0.339532 & 0.5770 & -0.028575 & 0.9570 \\
\hline $\mathrm{D}(\mathrm{EG})$ & 0.009830 & 0.3238 & 0.003397 & 0.8019 \\
\hline $\mathrm{ECT}$ & -0.710213 & 0.0015 & -0.544135 & 0.0054 \\
\hline $\mathrm{C}$ & -0.002245 & 0.9148 & -0.025031 & 0.1742 \\
\hline R-squared & 0.390634 & & 0.318152 & \\
\hline Adjusted R-squared & 0.303582 & & 0.220745 & \\
\hline Prob(F-statistic) & 0.013874 & & 0.041610 & \\
\hline
\end{tabular}

Noted: ECT: Error Correction Term

\section{CONCLUSION}

Based on the result of long term regression analysis, it was found that exchange rate in the form of direct term (Rp/USD) has negative impact to Indonesia's export, both to Singapore and Japan. The result of this study may happen in Indonesia because Indonesia's export is still dominated by commodities with prices that tend to decrease, thus the effect of weakening rupiah is very small compared to export increase. In the short term regression analysis, it was found that exchange rate and economic growth of trading partner countries do not have any impact to Indonesia's export. Error Correction Term (ECT) coefficient produces negative and significant value which mean that the convergence of export variable to reach equilibrium will occur if there is a shock in economy. Simultaneously, currency and economic growth variables influence Indonesia's export to Singapore and Japan both in short and long term. Findings of this empirical study shows that in the long term, the effect of the exchange rate to Indonesia's export to Japan is greater compared to Singapore. Subsequently, the effect of Singapore's economic growth to Indonesia's export is greater than the effect of Japan's economic growth. The policy to maintain the exchange rate in the right level to increase Indonesia's export, structural issue that needs to be addressed related to the domination of export commodity, and diversification of Indonesia's export market to new countries need to be done in light of the export growth to Singapore and Japan that tends to decrease. The policy to provide incentive to exporters can encourage exporters to keep their spirit in performing export activities thus impact to increase in export. The effort for diversification of Indonesia's export market to new countries needs to always be done to anticipate the decrease of supply of goods and services from Indonesia to main trading partner countries. 


\section{REFERENCES}

Bank of Indonesia, Indonesia's Statistic of Economy and Financial (various periods)

Budiono. (2015). Masyarakat ekonomi ASEAN 2015. Memperkuat sinergi ASEAN di tengah kompetensi global. Direkterot Internasional. Bank Indonesia

Bustaman, A. \& Jayanthakumaran, K. (2007). The impact of exchange rate volatility on Indonesia's exports to the USA: An Application of ARDL Bounds Testing Procedure. International Journal of Applied Business And Economic Research. 5 (1), 1-21.

Cheung, Yin-Wong \& Sengupta, Rajeswari. (2013). Impact of exchange rate movements on exports: an analysis of Indian non-financial sector firms. Journal of International Money and Finance. Elsevier. Vol. 39(C), Pages 231-245

Chit, Myint M. (2008). Exchange rate volatility and exports: evidence from the ASEAN-China free trade area. Journal of Chinese Economic and Business Studies. 6(3): 261-277.

Ekananda,M. (2016). Analisis ekonometrika time series. Penerbit. Mitra Wacana Media

Fitrianti, Shinta. (2017). T he exchange rate volatility and export performance: the case of Indonesia's exports to Japan and the US. Buletin Ekonomi Dan Perbankan Vol 20 No 1.

Grier And Smallwood. (2013). Exchange rate shocks and trade: a multivariate GARCH multivarian approach. Journal Of International Money And Finance. Vol. 37, Issue C, 282-305.

Gujarati, D. (2003). Basic Econometrics, $4^{\text {th }}$ edition. McGraw-Hill. Inc.

Hock-Tsen Wong dan Hock-Ann. (2016). Exchange rate volatility and exports of Malaysian manufactured goods to China: an empirical analysis International Journal of Business and Society. Vol. 17 No. 1, 2016, 145 - 159

Huchet-Bourdon \& Korinek. (2012). Trade effects of exchange rate and their volatility: Chili and New Zealand. OECD Trade Policy Paper No. 136. OECD Publishing.

Krugman, Paul R.; Obstfeld, Maurice Alih Bahasa Basri, Faisal H. (2004). International Economics. Ed.5, ISBN: 979-683-138-4. Penerbit: Indeks, Jakarta

Mankiw, N. Gregory. (2009). Macroeconomics, 7th Edition. Harvard University, Worth Publishers. New York.

Salvatore,D. (2013). International Economics, Eleventh Edition, Fordham University. ISBN 978-1-118-17793-8

Solakoglu Et Al. (2008). Exchange rate volatility and exports: a firm-level analysis. Journal Applied Economics. Volume 40, 2008 - Issue 7 Pages 921-929 | Published Online: 11 Apr 2011 